\title{
Formative Peer Feedback On Undergraduate Students' Speaking Ability
}

\author{
Erniyanti Nur Fatahhela Dewi $^{(1)}$, Nidyah Hasanah ${ }^{(2)}$, \\ \& Muhammad Faishol Nurul Huda ${ }^{(3)}$ \\ erni21yanti96@gmail.com,nindyahasanah@gmail.com,muhammadfaisalnh@gmail.com \\ Syarif Hidayatullah State Islamic University Jakarta, Indonesia
}

\begin{abstract}
This descriptive qualitative study investigated the undergraduate students' perception in public speaking class that conducted formative peer feedback, especially for undergraduate students who learned the subject at State Islamic University Jakarta. This study revealed the undergraduate students' perception about the implementation of formative peer feedback in assessing their formative public speaking class. Besides, the authors provided an open-ended questionnaire and semi-structured interview to know how applicable the formative peer feedback for undergraduate students, which part that students interested in when they assess their friends, and identify students' feelings when used the formative peer feedback in public speaking class. Concerning the results of the study, the writers discovered that formative peer feedback is very beneficial for the undergraduate student in the learning process of the public speaking class. While doing the assessment, most undergraduate students seem more interested in assessing their peer's body language and speech content. In addition, the result that the writers got from the investigation was $62.5 \%$ that claimed their peer's feedback was very objective. Other than that, when using the formative peer feedback in the public speaking class, $65.6 \%$ of undergraduate learners were feeling satisfied.
\end{abstract}

Keywords: Formative Peer Feedback; Undergraduate Students; Speaking Ability.

\section{A. INTRODUCTION}

Formative peer feedback is certainly one of the alternative formative assessments that students can utilize in pairs to explore, strengthen, and recognize their capability within the course. Formative peer feedback is assessing among students that are meant to strengthen their learning. Students might have the ability to feel free in expressing their ideas to each and every other. Moreover, Sari \& Setiawan (2018) argued that formative feedback is defined as communicative information for novices that might be 


\section{Erniyanti Nur Fatahhela Dewi, Nidyah Hasanah \\ \& Muhammad Faishol Nurul Huda}

Available Online at http://journal.iaingorontalo.ac.id/index.php/al

purposed to modify their considering or behavior to reinforce learning. Additionally, formative peer feedback has been used in English language courses to grasp the beginner's newbies' language efficiency within the four abilities, reminiscent of listening, speaking, reading and writing (Leenknecht \& Prins, 2018). Wanner and Palmer (2018) asserted that peer feedback requires appropriate design form and implementation in order to decide an efficient instrument for formative assessment procedures. Furthermore, formative peer feedback also creates students' capability to offer feedback, and the teacher's intervention is crucial for formative peer feedback.

Moreover, it seems interesting to observe formative peer feedback in enhancing the students' speaking ability since speaking is one of the subject matters in the Department of English Education. Nevertheless, many other teachers in Indonesia seem to find it challenging to provide a way of assessing the speaking skills of students, so they commonly use traditional methods. To illustrate, teachers ask each student to deliver individually in front of the class and provide them with the score, and it needs to spend more time assessing students' speaking ability as almost every class in Indonesia comprises even more than 30 students. According to Flucher (2018), speaking assessment in any foreign language is among the most challenging assessment activities suffered by teachers due to the students' amount and the time for learning.

In light of the formative peer feedback on students' speaking ability, it is going to assist students in minimizing the anxiousness of them. Formative peer feedback also is assumed to offer an impact on investigating the students' speaking ability. Therefore, Gikandi and Morrow (2016) assumed that formative peer feedback motivates students to participate actively within the finding out process. Regardless of increasing evidence that formative peer feedback forms helpful in making improvements to speaking abilities in students, comparable in deciding greater accountability for their learning process, creating a better understanding of the course, assessment requirements with their standards and evaluations, and creating important reflective and speaking abilities (Wanner and Palmer (2018). Against this, needs analysis of formative peer feedback as the assessment, attitudes of students to this tradition on undergraduate students' degree has no longer been investigated. Hence, gathering students' perceptions towards the use of formative peer feedback in exploring their speaking ability seems fascinating to be carried out in detail. 
Regarding this topic, some previous related studies discussed formative peer feedback, as mentioned by Elizondo-Garcia, Schunn, and Gallardo (2019), who examined the connection between high-quality pedagogical design peer feedback. In this regard, the observation was once carried out amongst 230 participants from Latini, the United States, within the Crisis Preparedness. Each qualitative and quantitative approach used to be carried out within the study. The qualitative design was carried out first to reveal the education practitioner's views and illustrate peer feedback aspects. Subsequently, the quantitative design was once used to check courses in keeping with peer feedback comments. The measurement instruments used have been a semistructure interview, demographic data survey, and peer feedback comments. Furthermore, the study results have supported the concept that educational design features, basically the guide structures and center of attention, decide the type of feedback that participants will produce and hence receive.

Sridaran and Boud (2019) researched the direct impact of formative efficiency and the interceding the results of praise and criticism in peer feedback messages on improving group work and self-assessment skills. This study attempts to defeat whether peer feedback leads to improving teamwork behavior and self-assessment abilities. Regarding this matter, this research pattern includes a quantitative and qualitative approach from 98 students. Students enrolled in the company are programmed using certain forms of collaborative teamwork. Besides, this study found a direct constructive relationship between formative efficiency scores and summative self-assessment abilities. Against this, the compliment negatively mediates the relationship between formative efficiency scores and summative group work.

In the other study, Peters, Körndle, and Narciss (2018) investigated a formative assessment script (FAS) to promote vocational high school students in producing feedback to their peer and their performance. The study examined producing peer feedback benefits the next generation vocational students from internal feedback. In this regard, the study was investigated concerning quantitative and qualitative peer characteristics and internal feedback produced by vocational students. It also conducted a quasi-experimental design. The study was involved 75 vocational students who created an individual assignment in writing a typical technical planning task as 


\section{Erniyanti Nur Fatahhela Dewi, Nidyah Hasanah \\ \& Muhammad Faishol Nurul Huda}

Available Online at http://journal.iaingorontalo.ac.id/index.php/al

participants. Furthermore, the result showed that FAS forced students to explore more critical ideas and omit fewer wrong elements in their choices.

Overall, those studies seem to indicate that formative peer feedback could positively impact students' learning experience and performance. However, those studies did not specifically discuss how undergraduate students' perceptions of implementing formative peer feedback improve speaking ability. Therefore, different from those previous studies, this current study would focus on investigating undergraduate students' perceptions of formative peer feedback in improving undergraduate students' speaking skills. Furthermore, the present study is aimed to address exploring the undergraduate students' perceptions using formative peer feedback towards speaking skills. To regard this study, collecting data will be gathered through a semi-structured interviewed questionnaire and measured by the qualitative method.

\section{B. RESEARCH METHOD}

A descriptive qualitative study was conducted in the study. It described the undergraduate students' perception who had experience in speaking class that conduct formative peer feedback. The description included undergraduate students' perceptions regarding their experiences in applying the formative peer feedback such as how applicable the formative peer feedback for undergraduate students, which part students like when they assess their friends and students' feelings. In this regard, thirty-two undergraduate students who had experience in using formative peer feedback invited to be a participant in The study. Additionally, the writers selected thirty-two undergraduate students of Syarif Hidayatullah State Islamic University Jakarta as the participants. It was due to the writers' consideration since the writers graduated from Syarif Hidayatullah State Islamic University. The writers had proximity emotional to undergraduate students that were used as the participants. Therefore, the writers had chosen the selected undergraduate students of Syarif Hidayatullah State Islamic University Jakarta.

Since the main data of the study perception, so that the authors used an online questionnaire (Google Form) to gather undergraduate students' perception about the implementation perceptions of formative peer Feedback in assessing their formative 
public speaking class. An online questionnaire with open-ended questions distributed to students, how applicable the formative peer feedback for undergraduate students, which part that students like when they assess their friends' and students' feelings. The questionnaire adopted from Munoz and Alvarez (2007) and the data from this recent study were analyzed using descriptive analysis. The writer also conducted a semistructured interview in order to measure participants' responses.

\section{FINDINGS AND DISCUSSION}

\section{Findings}

Participants in this research conducted a questionnaire that addressed undergraduate students' formative peer feedback perception in their capacity to speak in public speaking courses. Five open questions specifically addressed the reasons, perceptions, aspects of undergraduate students and their feedback on the implementation of peer feedback in public-speaking classrooms. It emerged after evaluating the questionnaire response and commonalities that are considered important and relevant to this research. In addition, the important topics arising from this research were that formative peer feedback help strengthen future performance, enhance motivation and stimulate them during their speaking performance, and enhance communication between undergraduate students and others. These topics are discussed below and arranged from the significance of the peer feedback questionnaire by each issue. There are five basic questions asked for accompanying opinions concerning the peer feedback and below the outcome the authors briefly explain the answer of each issue to the participants.

First, participants were asked about their views on implementing formative peer feedback in teaching and learning process, especially public speaking course. The result was presented as follows:
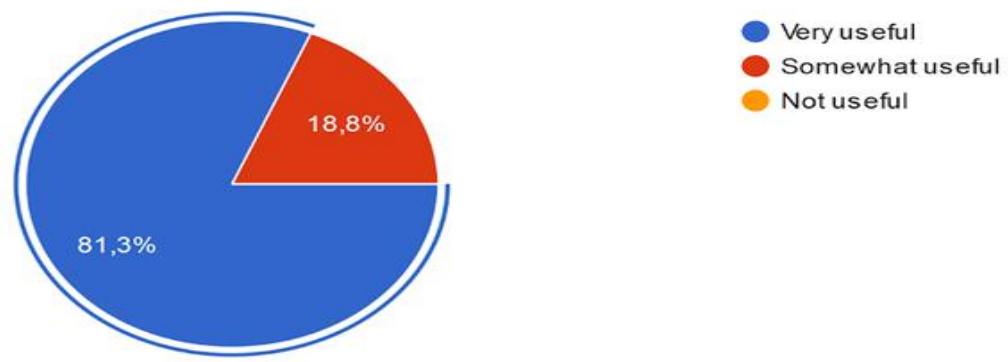

Figure 1. Views on implementing formative peer feedback 
The result of the data in chart above of 32 participants, 26 (81.3\%) asserted that they thought formative peer-feedback was very useful for them. There are four main reasons of the participant. First, through the formative peer feedback, it gave feedback for their peer. It meaned they were evaluating themselves. Second, formative peer feedback could improve participants' critical thinking. Their peer will stimulate to force them in improving their speaking performace. By their peer feedback, undergraduate students feel challenged to think more critically then that will produce more brilliant ideas than usual. Third, through the formative peer feedback, participants would be more confident since they know who assessed was their own friend, not the lecturer. Participants also stated that they were happy. They also aserted that they felt their confidence emerged in place of their speaking anxiety. Fourth, the participant thought that formative peer feedback could help them to realize their speaking ability. It could stimulate them to enhance their future performance so that participants could be more responsible for improving their speaking performance.

However, 6 (18.8\%) participants chose that formative peer feedback was somewhat useful for them. As participants who asserted the formative peer feedback was beneficial, the six participants also had some reasons to choose it. Writers categorized the reasons into two. First, the participant felt that their pair' ability was lower than him. It resulted that theirpeer feedback was not useful enough. Second, participants stated that the formative peer feedback who assessed by their friends could not be objective since they had an unpleasant feeling in criticizing. However, participant who chose somewhat useful were still recommend this peer feedback as optional assessment in the public speaking course.

Second, participants were asked about part that participants like most when they score their friends. The result was presented as follows:

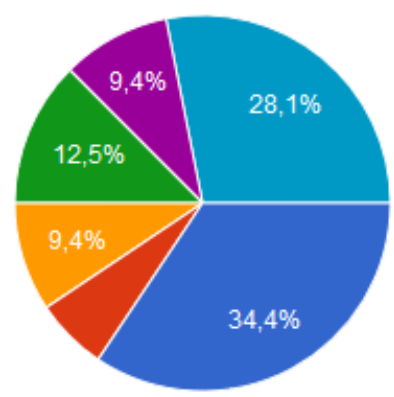

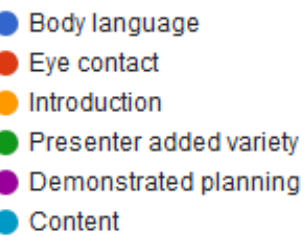

Figure 2. The part that participants like most when they score their friends 
The question two indicated the aspect in which students like to assess through peer feedback. From 32 participants, 11 of participants or $34.4 \%$ marked body language. There are various reasons stated by participants. Therefore, the writers categorize into four. First, participants said that body language showed the speaker's self-confident. Second, participants stated that using body language, the message would be easily delivered and understood by the audiences. In other words, body language helped the speakers' explanation. Third, participants mentioned that when the content which delivered was less attractive, the body language will support the speech. So, it will attract the audiences' attention. Fourth, the participant argued that since English was a foreign language, so, body language was very beneficial.

Moreover, 2 participants which is $6.3 \%$ from all participants chose eye contact. Participants reasoned that they like to see their peer's eyes. Through eye contact emission, they can see someone confidence clearly. On the other hand, introduction also chose by 3 participants and it was about $9.4 \%$, the participants argued that a good beginning significantly influenced the readiness of the audiences. It will stimulate the audiences continue listening to the presenter's talk. Participants also asserted that the introduction section is an "eye-catching" or something distinctive in general. Therefore, it can capture someone's interest in listening to that person's public speaking. The presentation which they presented was interesting if used the body language appropriately.

Another aspect that chose by 4 participants (12.5\%) is presenter added variety. Participants asserted that they chose this aspect since they felt when someone spoke would not even feel monotonous and could broaden their horizons. They knew whether or not the presenter mastered the content interestingly by combining other data. Another reason was because it could make viewers not easily bored in seeing the presentation delivered. In addition, demonstrated planning chose by $9.4 \%$ participants or about 3 persons. They mentioned that because the participants are visual learners, they chose this aspect. Moreover, it because they were more understanding when someone described visualization, and they can remember well the information provided than just describing it. Another reason is the way the presenter demonstrates it will be essential for the audience to understand the content presented. 


\section{Erniyanti Nur Fatahhela Dewi, Nidyah Hasanah \\ \& Muhammad Faishol Nurul Huda}

Available Online at http://journal.iaingorontalo.ac.id/index.php/al

The last aspect is content that chose by 9 participants (28.1\%). As other aspect before, undergraduate students who chose this aspect have several reasons. First, participants argued that Content aspect was an essential thing in carrying out the communication process. The communication process could be successful and wellreceived if the audience captured the meaning of the content which conveyed by the speaker. Second, the way to deliver the content of each person was different, so that the part was made participants interested in listening to the content, was what information conveyed while conducting an assessment in public speaking. Third, in assessing the content part, the evaluator would give the feedback that the presenter will know how much the influence of the speech and what part that should be more increased.

Third, participants were asked about whether they are objective or not when they score their friends. The result was presented as follows:

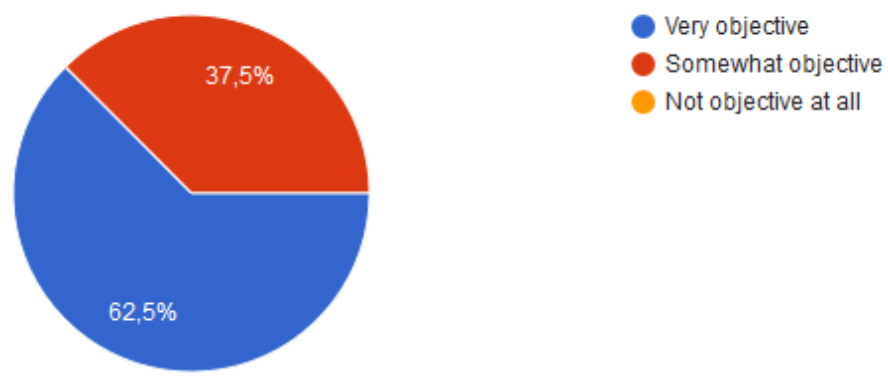

Figure 3. When I score my friend using the rubric, I am

In response to question three, $20(62.5 \%)$ of the participants responded very objective. Morever, 12 (37.5\%) participants responded somewhat objective, and no participants responded, not objective. Almost every undergraduate student indicated that they were very objective to assess their friends' performance using the peer feedback rubric. They realized that the result of the assessment did not only turn into a pile of garbage. It would become good suggestions so that they would undoubtedly have assigned the recommendations for improving their speaking ability. In other words, it used for knowing their weaknesses and making them better in speaking performance for the future chance. However, 12 participants chose somewhat objective because they felt inadequate to their friends to say honestly. Besides, if the friend who had not good performance enough, it was hard to comment on bad words. 
Fourth, participants were asked about their assumptions about whether their friends score their performance objectively or not. The result was presented as follows:

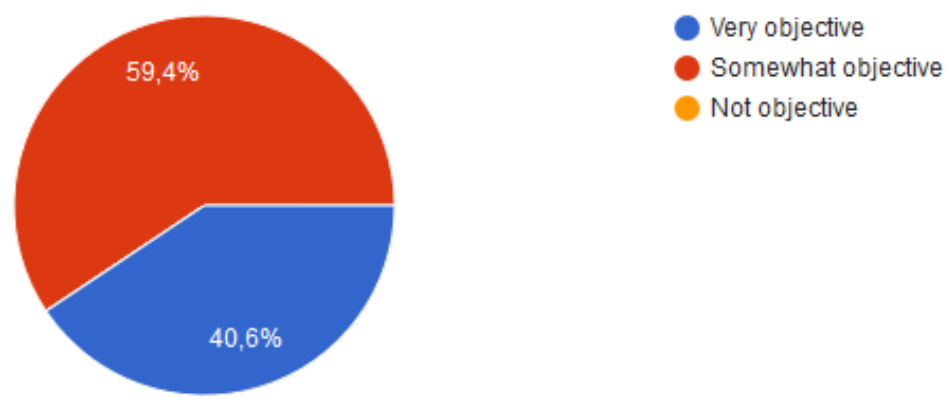

Figure 4. My friend's feedback

From the 32 participants who responded from the questionnaire that we provided, we have examined it and obtained outcomes of 19 (59.4\%) participants who chose friend's feedback is somewhat objective. When we gave direct interviews after collecting a questionnaire that we have shared, the friend's feedback was between objective and not objective, so most of them chose somewhat objective. They felt inadequate to their friends to say honestly and comment on bad words. Furthermore, 13 $(40.6 \%)$ of undergraduate students chose that students' feedback is not objective, because they believe that their abilities with each other were same, so that when their friends assess them, they felt doubtful to their friends, or sometimes they feel not objective because their friends assessed not from what they produced, but assessed them because just a friend.

Fifth, participants were asked about their feeling when using formative peer feedback in teaching and learning process, especially public speaking course. The result was presented as follows:

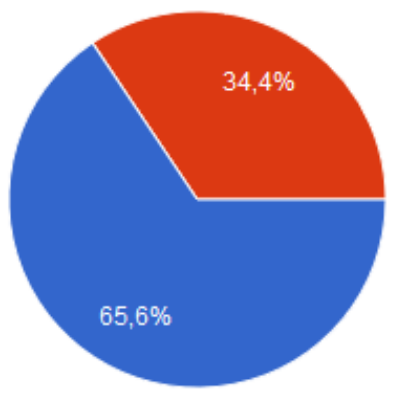

Very happy

Somewhat happy

Not happy

Figure 5. Paticipants' feeling when using formative peer feedback 
From 32 participants' responses that writers have already given the questionnaire, $34.4 \%$ undergraduate students chose somewhat happy to give the score to their friends using peer feedback instruments, they reasoned that they were happier and felt more comfortable when the teacher who gave them the formative assessment. Besides, we also had the results of $65.6 \%$ of responses who chose very happy because they gave the reason that using formative peer feedback was a new thing that they occasionally used to assess each other's friends, and they felt that if their friend gave an assessment, they feel freer to respond to each other's friends.

\section{Discussion}

The present study highlighted the obtained data on how the perception of undergraduate students in evaluating their speaking ability towards the enactment of formative peer feedback. The ideas among all the respondents showed that the formative peer feedback was very helpful to them because most of them figured that the peer feedback stimulated them to recognize how far their ability in oral performance. When students propose and give the feedback, Students interact with their pairs. Therefore, it influenced the independent learning. It is also evidenced by Yeh, Tseng and Chen (2019) who asserted that peer feedback effects discussion between students, their own taks reflection, and setting the approriate strategy to improve their abilities. It all resulted independent learning. Participants also believe that using peer feedback makes them expand their understanding so they can assess their friends. As stated by Comer, Clark and Canelas (2014) that peer feedback is information that allow students to exploretheir intention to modify their reflections or habits. In other case, it enhances student knowledge and expertise. Additionally, typical sequence of actions in peer feedback are efficiency and task completion, learn from one another, write and send feedback, receive feedback from others, and revise tasks.

Moreover, the study results also demonstrated that formative peer feedback could improve communication between undergraduate students with their peers since the peerassessment process that allowed students to have clarification and feedback from their friends. Through this process, undergraduate students may ask or discuss with their friend about some standards that they are still low at. For instance, when students assess the oral performance of their friend, some of them found that they were still low in pronouncing the words. Thus, students discuss it with their friend to have some 


\section{Erniyanti Nur Fatahhela Dewi, Nidyah Hasanah \\ \& Muhammad Faishol Nurul Huda}

Available Online at http://journal.iaingorontalo.ac.id/index.php/al

feedback on whether they should have electives to exercise or ask their friend to practice together in order to rehearse their pronunciation. This is significant since it is supported by Usher and Barak (2017), who found that engaging in peer assessment typically entails essential pondering and the implementation of high-level cognitive skills in producing thoughts and ideas.

In addition, the formative peer feedback also improves the students' incentive to achieve better performance, particularly oral performance. Through formative peer feedback, students can freely assess each other to know how far they accomplish or obtain the requirements. Therefore, it may increase their motivation to become a better for another performance chances. It is supported by Joo (2016), who said that Peer feedback motivate students to show the better oral performances. By students' motivation, it influenced students to be more active in participating discussion. They will truly encourage the discussion by giving quention and answer. In accordance, Ortoleva and Brètancourt (2016), Farias, Hastie, and Mesquita (2018), Nicolini and Cole (2019), and Cook (2019) agreed that students are able to generate new options in peer feedback actions that allow students to have questions and discussion.

\section{CONCLUSIONS}

Based on research finding, formative assessment is taken into account one of the vital necessary ways to enhance instructing and learning processes. It is performed to evaluate undergraduate students' understanding, learning wants, and learning progress regarding a selected unit of learning materials. Giving feedback in formative assessment is not only come and conducted by the lecturers, but also it may come from the students. Formative peer feedback is an alternative assessment that can be done by undergraduate students in evaluating, exploring, developing, and knowing their capability and knowledge. Since the implementation of formative peer feedback in Indonesia is still substitutive, it seems to indicate outstanding knowing undergraduate students' perception toward the implementation of formative peer feedback. Hence, in the present study, writers distributed the questionnaire and did a semi-structured interview to measure participants' responses.

Concerning the results of the study, the writers discovered that formative peer feedback could be very useful for the undergraduate students within the learning technique of public speaking class. While doing the assessment, most undergraduate 


\section{Erniyanti Nur Fatahhela Dewi, Nidyah Hasanah}

\& Muhammad Faishol Nurul Huda

Available Online at http://journal.iaingorontalo.ac.id/index.php/al

students like assessing the peer's body language and the content of the speech. What is more, $62.5 \%$ of the participants also assessed very objective. However, they felt their friend's feedback was somewhat objective. In addition, $65.6 \%$ undergraduate students felt pleased when using the formative peer feedback in public speaking class. 


\section{REFERENCES}

Comer, D. K., Clark, C. R., \& Canelas, D. A. (2014). Writing to learn and learning to write across the disciplines: Peer-to-peer writing in introductory-level MOOCs. International Review of Research in Open and Distributed Learning, 15(5), 26-82.

Cook, A. (2019). Using Interactive Learning Activities to Address Challenges of Peer Feedback Systems (Doctoral dissertation, Carnegie Mellon University).

Elizondo-Garcia, J., Schunn, C., \& Gallardo, K. (2019). Quality of Peer Feedback in Relation to Instructional Design: A Comparative Study in Energy and Sustainability MOOCs. International Journal of Instruction, 12(1), 1025-1040.

Farias, C., Hastie, P. A., \& Mesquita, I. (2018). Scaffolding student-coaches' instructional leadership toward student-centred peer interactions: A yearlong action-research intervention in sport education. European Physical Education Review, 24(3), 269-291.

Fulcher, G. (2018). Assessing Spoken Production. The TESOL Encyclopedia of English Language Teaching, 1-6.

Gikandi, J. W., \& Morrow, D. (2016). Designing and implementing peer formative feedback within online learning environments. Technology, Pedagogy and Education, 25(2), 153-170.

Joo, S. H. (2016). Self-and peer-assessment of speaking. Studies in Applied Linguistics and TESOL, 16(2).

Leenknecht, M. J., \& Prins, F. J. (2018). Formative peer assessment in primary school: the effects of involving pupils in setting assessment criteria on their appraisal and feedback style. European Journal of Psychology of Education, 33(1), 101116.

Munoz, A., \& Álvarez, M. E. (2007). Students' objectivity and perception of self assessment in an EFL classroom. The Journal of Asia TEFL, 4(2), 1-25.

Nicolini, K. M., \& Cole, A. W. (2019). Measuring peer feedback in face-to-face and online public-speaking workshops. Communication Teacher, 33(1), 80-93.

Ortoleva, G., \& Bétrancourt, M. (2016). Supporting productive collaboration in a computer-supported instructional activity: peer-feedback on critical incidents in health care education. Journal of Vocational Education \& Training, 68(2), 178197. 
Peters, O., Körndle, H., \& Narciss, S. (2018). Effects of a formative assessment script on how vocational students generate formative feedback to a peer's or their own performance. European Journal of Psychology of Education, 33(1), 117-143.

Shute, V. J. (2008). Focus on formative feedback. Review of educational research, 78(1), 153-189.

Sridharan, B., \& Boud, D. (2019). The effects of peer judgements on teamwork and self-assessment ability in collaborative group work. Assessment \& Evaluation in Higher Education, 44(6), 894-909.

Usher, M., \& Barak, M. (2018). Peer assessment in a project-based engineering course: comparing between on-campus and online learning environments. Assessment \& Evaluation in Higher Education, 43(5), 745-759.

Wanner, T., \& Palmer, E. (2018). Formative self-and peer assessment for improved student learning: the crucial factors of design, teacher participation and feedback. Assessment \& Evaluation in Higher Education, 43(7), 1032-1047.

Yeh, H. C., Tseng, S. S., \& Chen, Y. S. (2019). Using online peer feedback through Blogs to promote speaking performance. Journal of Educational Technology \& Society, 22(1), 1-14. 